\title{
The Mastery Of Cognitive, Affective, And Psychomotor Domains On The Students' Decision To Be Entrepreneurs In Facing Towards Asean Economic Community-2015
}

Lutfatul Amaliana ( $\square$ luthfatul.ub@gmail.com )

Brawijaya University, Malang, Indonesia

Research

Keywords: Cognitive, Affective, Psychomotor Domain, Entrreprneurs

Posted Date: February 17th, 2020

DOl: https://doi.org/10.21203/rs.2.23708/v1

License: (9) This work is licensed under a Creative Commons Attribution 4.0 International License. Read Full License 


\section{Abstract}

The purpose of this study was to analyze the depth of student understanding in the cognitive, affective, cognitive, and psychomotor domains of Entrepreneurship subjects by using a contextual learning approach to the decision to become entrepreneurs. This research used a descriptive research method with qualitative and quantitative approaches. Descriptive analysis was conducted because this research only gave an overview of the learning conditions in the classroom during the learning process and analyzes the learning outcomes in Entrepreneurship subject by using Contextual Teaching and Learning. Contextual learning (CTL) can be used to increase student participation in discussions, the results of the depth of students' understanding of cognitive, affective, and psychomotor domains have a positive effect on the decision to become entrepreneurs. No previous research comprehensively investigated the domains of cognitive, affective, and psychomotor in the decisions of students to become entrepreneurs in the face of the ASEAN-2015 economic community. This is not only to reduce the rising unemployment rate, but also to face the inevitable changes in the social and economic conditions of the world.

\section{Introduction}

There are several reasons why entrepreneurial learning becomes more important to understand and apply in contextual and innovative learning in the developing countries. The reasons at least include; (1) Challenges of Both Regional and Global Cooperation and Competition, (2) Suppressing unemployment rates that tend to increase over time, (3) The increasing human needs due to change of lifestyle, (4) Population growth, and (5) Preparing the young generation to enter a potential world of business (Soemanto, 1984, Sumahamijaya et al., 2003, Basri, H 2013).

In the global context, entrepreneurship becomes more important to develop, because it is considered effective to improve people's welfare through its contribution to the increasing economic growth as well as equity of economic growth. The emerging market economies, such as China and India are the examples of countries that have millions of new tough and globally-competitive entrepreneurs (Joewono, 2011).

Entrepreneurship Education and Social Changes - Global Economy. The processes and objectives of education in both formal and informal institutions are always expected to have a positive effect on someone's life, especially for students. According to Bloom (1956) the objectives of education are divided into several domains, namely (1) Cognitive Domain, that is building or providing knowledge, thinking skills to students in accordance their interests, (2) Affective Domain, which equips the students with values, feelings, emotions, interests, appreciation, adaptation, and noble attitudes, in their behaviors, and (3) Psychomotor Domain, which provides various skills to the students in order to be used for their lives in the community according to their interests and talents. While in another version as stated by Ki Hajar Dewantoro, the aspects of Creating, Sense, and Intention (Cipta, Rasa, Karsa) or with other terms that is; reasoning, appreciating, and practicing (Sukmadinata, 2005, Makmun, 2003, Gendler, 1992, Krathwohl, 1964). Based on these views, education is expected to be able to prepare reliable human resources to 
master science and technology, and have noble attitudes in various fields of life to achieve the welfare of a nation.

Soehendro (1997) states that "It is not easy to predict the future, but it is assured that science and technology are the main sources of economic growth and the advancement of people's lives in different countries". Globalization which is essentially an economic engineering has made human life to be so open, and in such openness, human beings are the key factor. With a high quality of human beings, it is possible to produce a variety of commodities needed in world trade, although the related country does not have the necessary natural resources. Such openness also encourages the flow of new technology from the developed countries. In this process, education plays a determinant role since education encourages the adoption or transfer, adaptation and distribution of technology (Sutanto, 2002).

The entrepreneurial learning in developing countries, such as Indonesia, today, needs to be increasingly driven to achieve satisfactory results. It is not only to reduce the increasing unemployment rate, but also to face the unavoidable changing conditions of the social and economic environment of the world. In the near future, Indonesia will face the era of Asean Economic Community (AEC)-2015. In facing this condition, the educational institutions as the institutions that play a role in preparing human resources, especially for higher education institutions, should quickly respond to such changes. In addition, the universities have shifted from the paradigm of Learning University, to Research University and further to Enterpreneurial University (Wirasasmita, 2000).

In practice, most universities are still limited to provide entrepreneurship materials to students. Likewise, the entrepreneurship materials provided are limited to the mastery of cognitive aspect (entrepreneurial knowledge). It lacks of depth in the materials which is able to reach the affective aspect (mastery of attitudes) as well as to the psychomotor aspect (mastery skills). Thus, it will bring gaps in facing the real conditions in society. Until now, in some educational institutions, especially for the higher education level, the gap of mastery of these three domains is still far from what is expected.

Creative and Innovative Learning. At a glance, the results of field observations showe that the current learning is more on passing down the ability in terms of cognitive domain, which is far away from the affective domain, moreover, from the psychomotor domain. As a result, learning lacks of having the attitude values and lacks of skills. Students are more emphasized on the ability to memorize what they have studied. In many cases, in general, it is believed that the ability to memorize only lasts in a relatively short time. Based on the observations, most students tend to memorize about the meaning learned at the time of facing the examination. When the examination has been finished, in general, the concepts that have been memorized begin to fade slowly and lost completely after a while. This condition provides an illustration that the learning method used has many limitations and weaknesses. Students come to the college only for having a seat, listening, and taking notes, so as making them less creative and innovative. Such problems are caused by the use of lecturing method which only emphasizes the understanding of the cognitive domain or concerns the mastery of the concept of knowledge only. While the achievement of the affective and psychomotor domains is very limited. 
Basically, the ideal educational process should pay attention to three important aspects as expressed in Bloom's taxonomy, namely the cognitive, affective and psychomotor aspects. If the learning process is able to accommodate these three aspects, the output of education will be able to produce high quality and highly competitive graduates. The creative and innovative graduates will be able to anticipate changes and development in society, otherwise, if the education process ignores these aspects and only focuses on one aspect only. It will have an output of non-creative education which will not be able to anticipate the changes and development in society that go rapidly. The creative and innovative graduates are needed by today's global era. Creativity development on students started from the early ages will be able to form the habits of intelligent way of thinking of the students in the future. According to Jacobson (1989), creativity is defined as the use of imagination and ingenuity to produce an approach thought to obtain a unique solution in overcoming the problem. Creative and innovative learning will be able to generate human resources with independent attitude in life. One of the ways to improve the creativity of the students is by applying a learning model that is more relevant to the real world. By involving the students into the real conditions, it is expected to generate the alternative and diverging thoughts to the students. Therefore, the lecturers are expected to be able to teach dynamically, thematically and contextually. Contextual learning model is expected to generate a variety of alternative and diverging thoughts from learners. Based on this fact, according to Suyanto (2000), the conventional classical learning system that relies solely on speech-lecturing model should be combined with a more active CTL model in order to be able to realize the strong mastery of affective and psychomotor domains in order to face a better future.

Research Objectives. The objectives of this research are; (1) to analyze the depth of students' comprehension in the cognitive domain of Entrepreneurship subject by using contextual learning approach; (2) to analyze the depth of students' comprehension in the affective domain of Entrepreneurship subject by using contextual learning approach, (3) to analyze the depth of students' mastery in the cognitive domain of Entrepreneurship subject by using contextual learning approach, 4) to analyze the effect of the deep comprehension in the cognitive, affective, and psychomotor domains on the decision to be entrepreneur.

\section{Research Method}

This research used a descriptive research method with qualitative and quantitative approaches. Descriptive analysis was conducted because this research only gave an overview of the learning conditions in the classroom during the learning process and analyzes the learning outcomes in Entrepreneurship subject by using Contextual Teaching and Learning.

The target population of this study was the students of Economics Education Study Program who attended the Entrepreneurship subject in the academic year of 2015-2016 with a total of 84 students from two parallel classes. By using proportionate sampling technique, there were $50 \%$ of the students taken from each class, thus, the sample size was 42 students. 
Primary data were obtained through: (1). Students' activities during learning activities; (2). Students' responses to learning activities; (3). Students' learning outcomes in Entrepreneurship subject. These three aspects were obtained through: (1). Test (written test) to obtain the data of learning outcomes before and after the learning activities which covered the cognitive, affective, and psychomotor domains. (2). Participatory observation is to obtain the data of students' activities during learning activities. The observations were conducted by using an observation sheet.

The quantitative analysis was formulated with the following model:

$$
\begin{aligned}
& K P W=f(K G N, A F T, P S K) \\
& K P W=\text { Decision to be Entrepreneur }(Y) \\
& f=\text { function } \\
& K G N=\text { Cognitive Domain Comprehension }(X 1) \\
& \text { AFT = Affective Domain Comprehension (X2) } \\
& \text { PSK = Psychomotor Domain Comprehension (X3) }
\end{aligned}
$$

\begin{tabular}{|c|c|c|c|}
\hline$\overline{\text { No }}$ & Variable & Indicator & $\begin{array}{l}\text { Measurement } \\
\text { Scale/Score }\end{array}$ \\
\hline 1 & $\begin{array}{l}\text { KGN = Cognitive } \\
\text { Domain Comprehension (X1) }\end{array}$ & $\begin{array}{l}\text { 1. High Category }(\mathrm{T}) \text { answered }> \\
35 \text { questions } \\
\text { 2. Moderate Category }(\mathrm{S}) \text { answered 34- } \\
20 \text { questions } \\
\text { 3. Low Category }(\mathrm{R}) \text { answered }< \\
20 \text { questions }\end{array}$ & $\begin{array}{l}\mathrm{T}=3, \quad \mathrm{~S}=2, \mathrm{R} \\
=1\end{array}$ \\
\hline 2 & $\begin{array}{l}\text { AFT = Affective } \\
\text { Domain Comprehension (X2) }\end{array}$ & ditto & ditto \\
\hline$\overline{3}$ & $\begin{array}{l}\text { PSK = Psychomotor } \\
\text { Domain Comprehension (X3) }\end{array}$ & ditto & ditto \\
\hline$\overline{4}$ & $\begin{array}{l}\text { KPW = Decision to be } \\
\text { Entrepreneur }(Y)\end{array}$ & $\begin{array}{l}\text { 1. High Motivation (T) answered }> \\
35 \text { questions } \\
\text { 2. Moderate } \\
\text { Motivation (S) answered } 34-20 \text { questions } \\
\text { 3. Low Motivation (R) answered < } \\
20 \text { questions }\end{array}$ & ditto \\
\hline
\end{tabular}

\section{Table: 01. Variable Measurement}

\section{Results}

The results provide some overviews as follows: 
Students' Activities During Learning. The observation on students' activities during learning provides some overviews as follows: Student Participation in Group Work. The results of observation on the participation of 42 students in group work; high category $(T)=12$ students $(28,58 \%)$, moderate category $(S)=15$ students $(35,71)$, and low category $(R)=15$ students $(35,71)$. The indicators of student participation in the group include; (a) organize the group, (b) direct the group, (c) prepare the learning equipment for group work needs, (d) prepare the draft of final group assignment, (e) provide input for the finalization of the final group assignment, and (f) determine/distribute the role of group members for the presentation of group discussion.

The Quality of Presentation of Discussion Results, The results of the analysis for the presentation of the group discussion results in the classroom showed; high category $(T)=10$ students $(23,81 \%)$, moderate category $(S)=18$ students $(42,87 \%)$, and low category $(R)=14$ students $(33,32 \%)$. The indicators assessed include; (a) the quality of assignment is suited to the predetermined substance/format, (b) the quality of material contents (c) the quality of the presentation, (d) equal distribution of roles in giving responses, (e) the ability to effectively control the discussion, and (f) the liveliness and compactness of the group in giving responses.

Student Participation in Classroom Discussion. The results of the analysis for the student participation in group discussion in the classroom showed that the high category $(T)=20$ students $(47,62 \%)$, moderate category (S) 12 students $(28,57 \%)$ and low category $(R)=10(23,81 \%)$. The indicators include; (a) textless questions, with good reasoning and effective language use, (b) textless questions, with moderate reasoning and effective language use, (c) text questions, with low reasoning and less effective language use.

Students' Verbal Presentation of the Reviews Description. The verbal presentation of a description review in the classroom discussion is based on the following criteria; (a) courage, (b) enthusiasm, and (c) selfconfidence in presenting his or her opinion. high category $(T)=21$ students $(50,00 \%)$, moderate category (S) 11 students $(26,19 \%)$ and low category $(R)=10$ students $(23,81 \%)$.

The Ability to Construct Meaning. The ability to construct meaning was assessed from the results of group assignment submitted by the students to analyze entrepreneurial knowledge, questions about entrepreneurial attitudes, and questions related to entrepreneurship skills. Based on the observation results, the data obtained as follows: high category $(T)=12$ students $(28,57 \%)$, moderate category $(S)=9$ students $(21,43 \%)$ and low category $(R)=21$ students $(50,00 \%)$.

Students' Responses to Learning Activities. Students' responses to learning activities and the developed learning tools filled by the students after the learning activities finished. The data of students' responses to the learning components showed that $90,48 \%$ of the students were satisfied on each component of learning activities, $85,71 \%$ of the students said that the components of learning activities are new to them, while $95,24 \%$ of the students stated that the learning model applied by lecturers helped them in mastering the Entrepreneurship materials. While there is no perceived obstacles relatively. 
Students' learning outcomes. The Depth of Students' Comprehension. The results of the test for each domains are as follows: Cognitive Domain (Entrepreneurial Knowledge) Comprehension. The results of the research related to the cogative domain had been formulated in the form of questions for 60 pieces in the form of 5 choices which include the ingenuity in mastering the entrepreneurial theories and knowledge, gave the following overview; high category $(T)$ was for those who were able to answer $>35$ questions, with a percentage of $71,43 \%$, moderate category (S) was for those who were able to answer $34-20$ questions, $23,81 \%$, and low category (R) was for those who were able to answer $<20$ questions, with a percentage of $4,76 \%$. Based on these results it can be said that most of the students have a good comprehension on the cognitive domain. It was only $4,76 \%$ for those who have less comprehension on the cognitive domain. Entrepreneurial theories were given starting from; (a) have ever known and read 5 required literatures about entrepreneurship, (b) the importance of entrepreneurship, (c) the definition, function and role of entrepreneurship, (d) the characteristics of entrepreneurs, (e) fields of entrepreneurship, (f) supporting and inhibiting factors of entrepreneurship, and (g) entrepreneurial motivation.

Affective Domain (Entrepreneurial Attitude) Comprehension. The affective domain comprehension has also been formulated into 60 questions in the form of 5 choices that include the ability to assess and to be positive in entrepreneurship. Otherwise, those who did not have a positive attitude provided incorrect answers which gives the following overviews; high category $(T)$ was for those who were able to answer > 35 questions, with a percentage of 59,52\%, moderate category (S) was for those who were able to answer $34-20$ questions, with a percentage of $23,81 \%$, and low category $(R)$ was for those who were able to answer $<40$ questions, with a percentage of $16,67 \%$. Based on the data, it can be said that most students have a positive attitude on entrepreneurship. It was only a small percentage of $16,67 \%$ who have negative attitude on entrepreneurship.

Psychomotor Domain (Entrepreneurial Skills) Comprehension. The psychomotor domain (entrepreneurial skills) comprehension has also been formulated into 60 questions in the form of 5 choices that include the followings; (a) the ability to determine the fields of entrepreneurship available in society, (b) provide solutions to business risks, (c) capital solutions, (d) marketing networks, (e) Partnerships and cooperation, (f) face the competitive business conditions, and (g) Efficient resource options. The results of the research provided some overviews, as follows; high category $(T)$ was for those who were able to answer $>35$ questions, with a percentage of $76,19 \%$, moderate category (S) was for those who were able to answer 34-20 questions, with a percentage of $14,29 \%$, and low category (R) was for those who were able to answer $<40$ questions, with a percentage of $47,62 \%$. Based on the data, it can be said it was only a small percentage of students of $9,52 \%$ who have less mastery on the psychomotor domain. The observation showed that the students have obtained the practical knowledge in the field of entrepreneurship, although the intensity of practice was very limited considering that the practical/workshop facility available in previous education level was also very limited.

Decision to be Entrepreneur. The variable decision to be entrepreneur was measured with an indicator of interest on entrepreneurship. Although this study was conducted on the students of economics education 
(obtain teching educations to work as teachers), but it was assumed that even though they would be teachers they still have an option to be entrepreneur. Moreover, it is very limited for teacher positions, especially for civil servant teachers, so that it is inevitable for the students to be enthusiastic to be entrepreneurs.

The results of the study on the decision to be entrepreneur provided an overview that from 42 students observed, 35 students $(83,34 \%)$ have high motivation $(T)$ to be entrepreneurs, 5 students $(11,90 \%)$ have moderate motivation (S) to be entrepreneurs, and 2 students $(4,76 \%)$ have low motivation $(R)$ to be entrepreneurs.

\section{The Effect of Depth of Comprehension on Cognitive, Affective, and Psychomotoric Domains on the} Decision to be Entrepreneur. The analysis of the effect of three independent variables, namely cognitive domain comprehension (X1), affective domain comprehension (X2), and psychomotor domain comprehension $(\mathrm{X} 3)$, on the dependent variable, namely decision to be entrepreneur $(\mathrm{Y})$ showed a significant effect. The results of regression calculation obtained a coefficient of determination of 0,72 (72\%). It means that if the knowledge (cognitive), values (attitude) and skills variables increased by $1 \%$, the variable decision to be entrepreneur will increase by $72 \%$. While the remaining $28 \%$ is still affected by other variables other than the three variables. While the correlation coefficient of these three variables simultaneously showed a strong relationship between the cognitive, affective and psychomotor variables and the decision to be entrepreneur, with a correlation coefficient of 0,85 .

The results of the calculations by using IBM-SPSS Statistic version 20 can be seen in the following table;

Model Summary

\begin{tabular}{|l|c|r|r|r|}
\hline Model & $\mathrm{R}$ & $\mathrm{R}$ Square & Adjusted R Square & Std. Error of the Estimate \\
\hline 1 &, $852^{\mathrm{a}}$ &, 726 &, 704 &, 28271 \\
\hline
\end{tabular}

a. Predictors: (Constant), VAR00003, VAR00001, VAR00002

\section{Discussion}

Based on the description of the results above, it can be explained that if someone has been equipped with knowledge, values or attitudes, and also certain skills to certain thing, then it will have a strong implication to certain thing done as a decision of his/her choice. Similarly, in the decision to be entrepreneur. The entrepreneurial knowledge during the education period has a positive implication on the decision to be entrepreneur. Similarly, the values (attitudes), and as psychomotor (skills) variables also have a positive implication on the decision to be entrepreneur. Therefore, the adequate knowledge, attitudes, and skills, should be further strengthened in every educational process in order to generate a youth generation which tend to decide to be entrepeneur in the future. Thus, a nation will be able to generate more reliable human resources as new entrepreneurs who are needed in order to encourage the economic growth and prosperity of the nation, moreover, when facing the increasingly competitive and unlimited global environment. Likewise, in terms of knowledge, values, and skills in cooperation. Since the widely open market space between countries in a region, such as Asean, will soon enter the era of 
economic integration, it is expected that the human resources of Indonesia and especially for human resources in Aceh, to be not only as spectators, but as the more active actors performing a certain role in both global and regional economic activities.

\section{Recommendations}

By observing the processes and results of learning that have been conducted using CTL learning model in Entrepreneurship subject, the recommendations are as follows;

\section{Educational Institutions}

Educational institutions (FKIP), especially in Economics Education study program, need to provide more space for entrepreneurship practices for students at the final year, so that they are better equipped to face the competitive conditions of getting jobs in the future, especially with the enactment of AEC-2015. The efforts taken need to provide laboratory contents or facilities for entrepreneurial workshops that are relevant to students' interests and talents.

\section{Family and Community}

Family and community need to encourage children to cultivate the entrepreneurial spirit earlier by making them realize that their future will be full of competition in obtaining economic resources. The efforts can be made by practicing economic efforts in family environment in accordance with existing potentials, such as conducting a micro enterprise in various business cores.

\section{Government}

The government can provide assistance for senior students at the final year in various forms, such as specificied training in various fields, such as; business management, accounting, marketing and funding schemes.

\section{Business World}

The business world can also have significant contribution in helping students to link and match program with educational institutions more intensively, so that the students can draw on the real knowledge faced by the business world, such as apprenticeships, employment contracts, joint researches and so on.

\section{Conclusions}

Based on the analysis result above, the conclusion of this research are (1) Contextual learning (CTL) can be used for improving student participation in discussions with various entrepreneurial themes, improving the quality of the presentation of the results of discussion, improving the verbal presentation of the description review, and improving students' ability to construct meaning or concept. (2) There are some weaknesses found in the implementation of CTL, among others; the continuous use of CTL can make 
students getting bored, the use of CTL requires high costs, both in terms of media creation and for observation purposes. For the students who have high motivation to learn, they will feel happy because there will be many opportunities to express their opinions, otherwise, for students who have low motivation, they will tend to be passive (less interested). (3) The results provide some overviews, as follows; the depth of students' comprehension on cognitive, affective, and psychomotor domains variable have positive implication on the decision to be entrepreneur. This condition can be seen from the coefficient of determination obtained of 0,726 . While the correlation coefficient was 0,852 . Thus, the depth of students' comprehension on the three domains has a significant effect on and a strong relationhsip with the decision to be entrepreneur.

\section{References}

Basri, H. (2013). Landasan Pendidikan. Bandung: Pustaka Setia.

Bloom, B. S. (1956). Taxonomy of educational objectives. Vol. 1: Cognitive domain. New York: McKay, 2024.

Burhan, Umar \& Munawar Ismail .1988. Koperasi Produksi, Karunika, Jakarta.

Gendler, E. (1992). U.S. Patent No. 5,092,887. Washington, DC: U.S. Patent and Trademark Office.

Jacobson, G. (1989, October). Space-efficient static trees and graphs. In Foundations of Computer Science, 1989., 30th Annual Symposium on (pp. 549-554). IEEE.

Joewono, H. (2011). Strategi Pengembangan Kewirausahaan Nasional Sebuah Rekomendasi Operasional. Jurnal Infokop Volume 19 Juli 2011.

Krathwohl, D. R. (1964). The taxonomy of educational objectives: Its use in curriculum building. Defining educational objectives, 19-36.

Soehendro, B. (1997). Kebijakan Pemerintah dalam meningkatkan mutu pendidikan tinggi di Indonesia. Buletin Pendidikan Tinggi, Ditjen Pendidikan Tinggi, Edisi Pertama Bulan Mei, h, 9.

Soekartawi. 1990. Teori Ekonomi Produksi, Rajawali Pers, Jakarta.

Soemanto, W. (1984). Psikologi pendidikan: Iandasan kerja pemimpin pendidikan. PT. Bina Aksara.

Sukmadinata, N. S. (2005). Penelitian Tindakan Kelas.

Sumahamijaya, S., Yasben, D., \& Dana, D. A. (2003). Pendidikan Karakter Mandiri dan Kewiraswastaan. Bandung: Angkasa.

Sutanto, R. (2002). Penerapan Pertanian Organik: pemasyarakatan dan pengembangannya. Kanisius. Syamsuddin Makmun, A. (2003). Psikologi Pendidikan. Bandung: PT Rosda. Karya Remaja. 
Wirasasmita, Yuyun .2000.. Kewirausahaan di Perguruan Tinggi, Makalah UNPAD, Bandung.

\section{Declarations}

Availability of data and materials : This research used a descriptive research method with qualitative and quantitative approaches. Descriptive analysis was conducted because this research only gave an overview of the learning conditions in the classroom during the learning process and analyzes the learning outcomes in Entrepreneurship subject by using Contextual Teaching and Learning.

Funding: This study was self-funded.

Conflict of Interest: The authors declare that they have no conflict of interest.

Ethical approval: This article does not contain any studies with human participants performed by any of the authors.

\section{Figures}

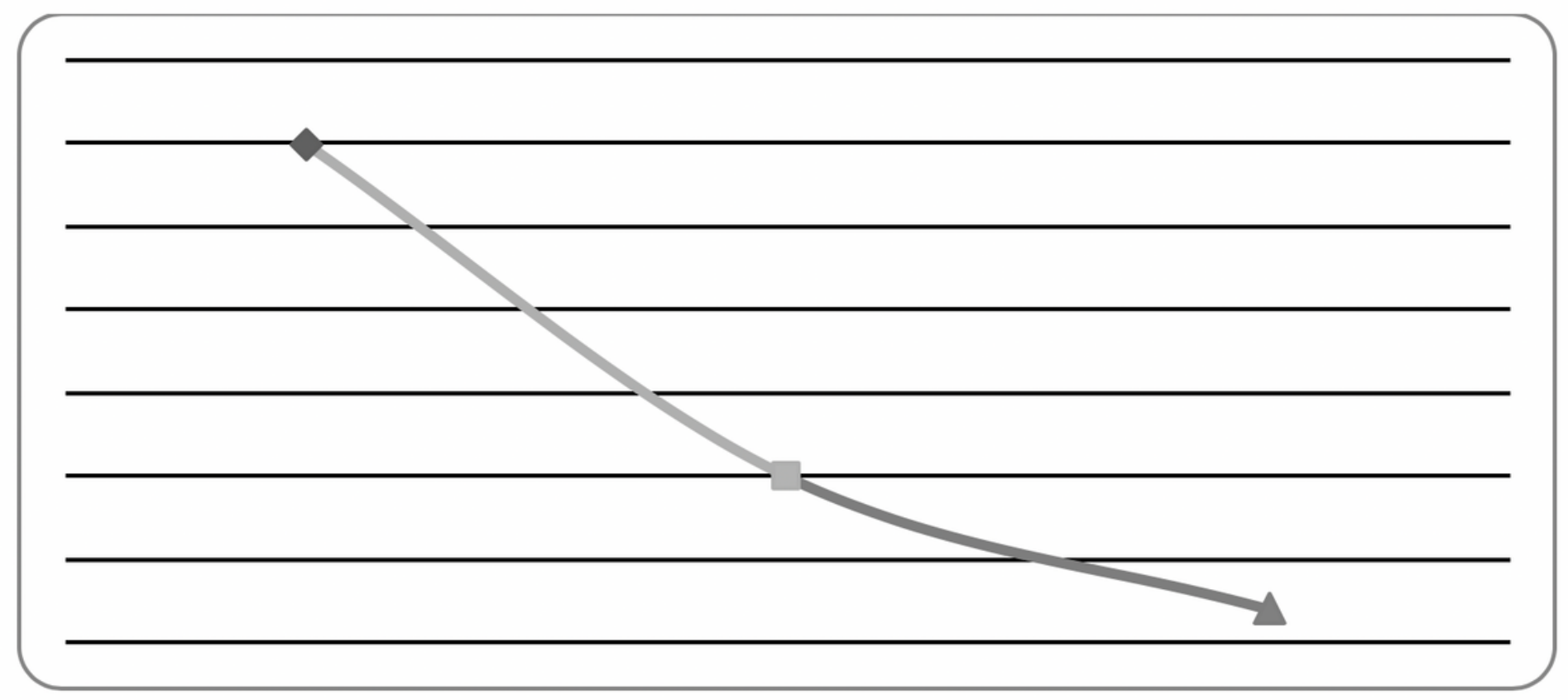

Figure 1

Table: 02. Cognitive Domain Comprehension 


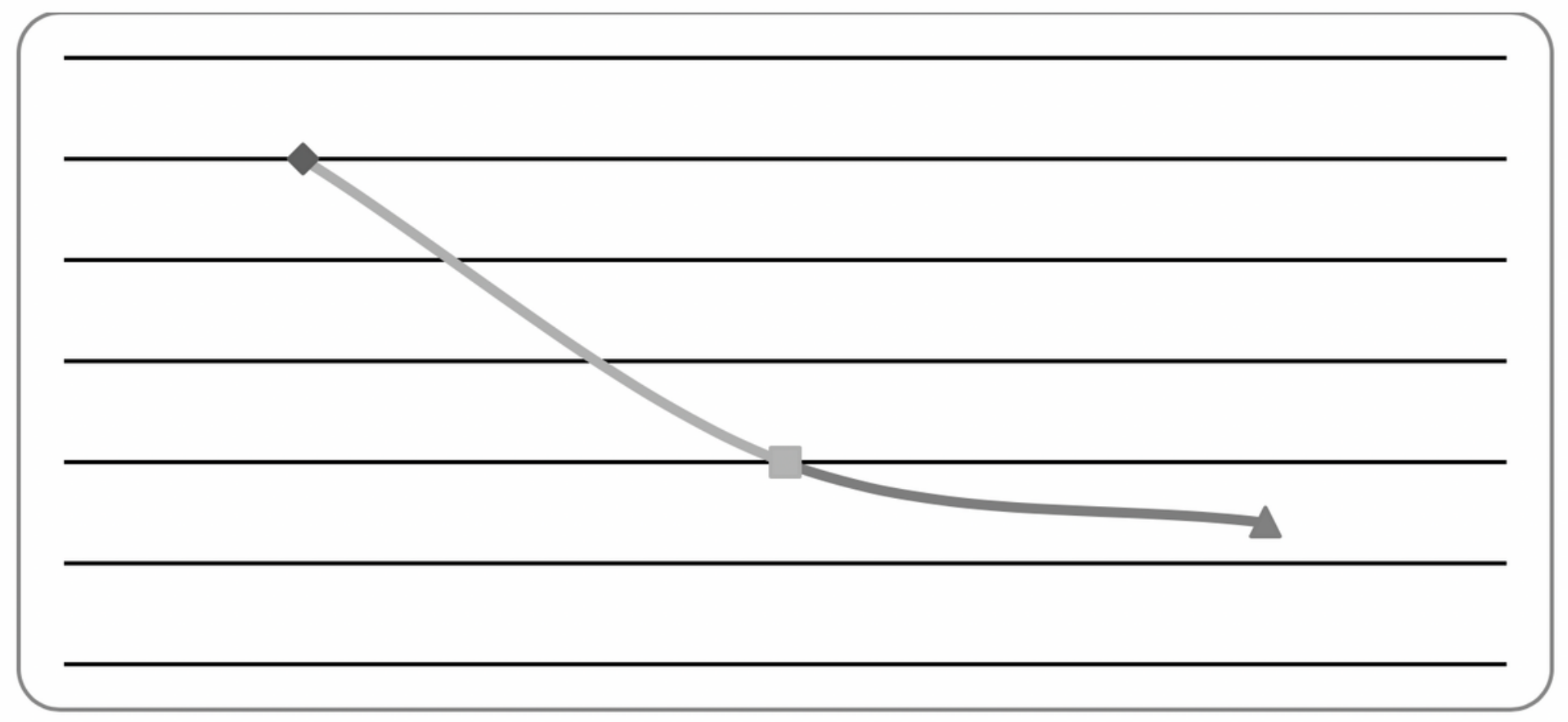

Figure 2

Table: 03. Affective Domain Comprehension

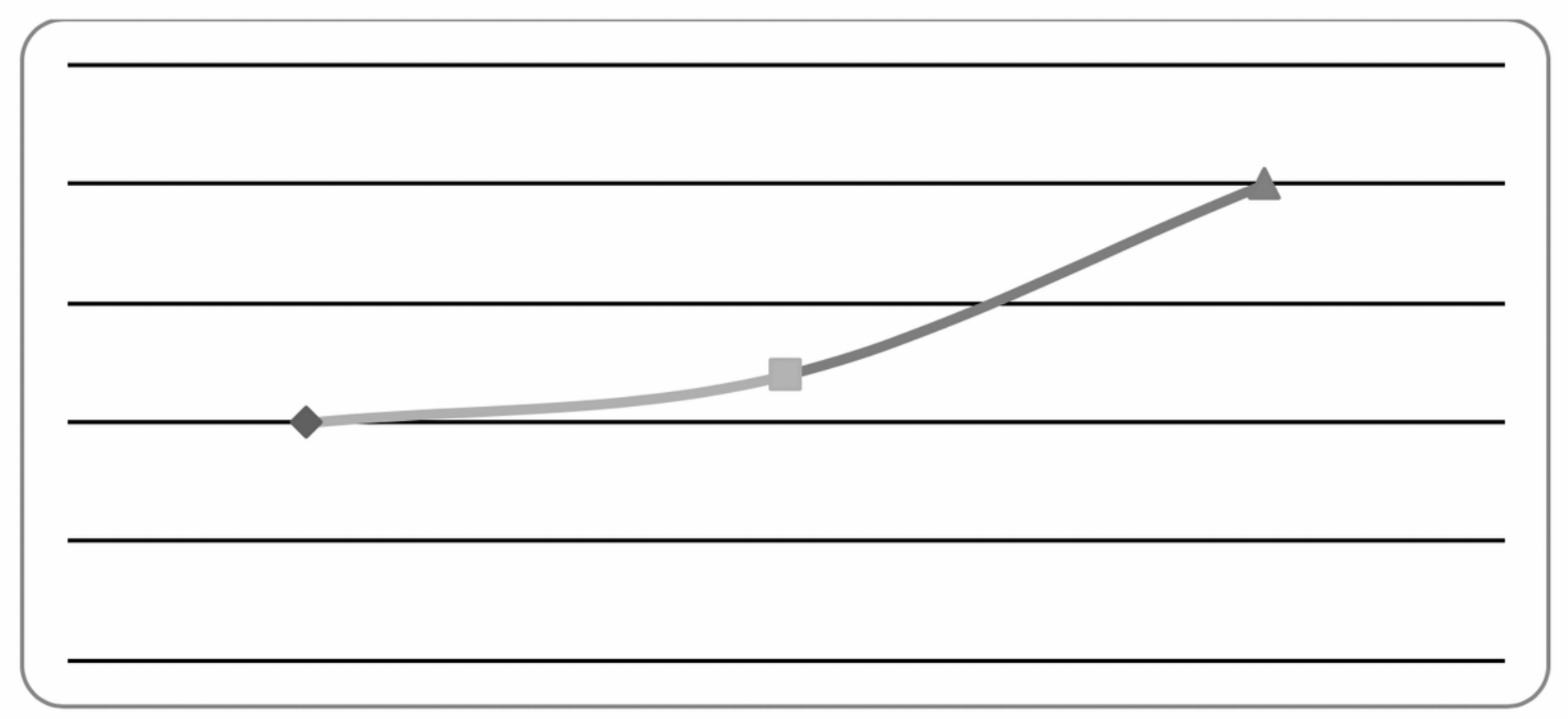

Figure 3

Table: 03. Psychomotor Domain Comprehension 


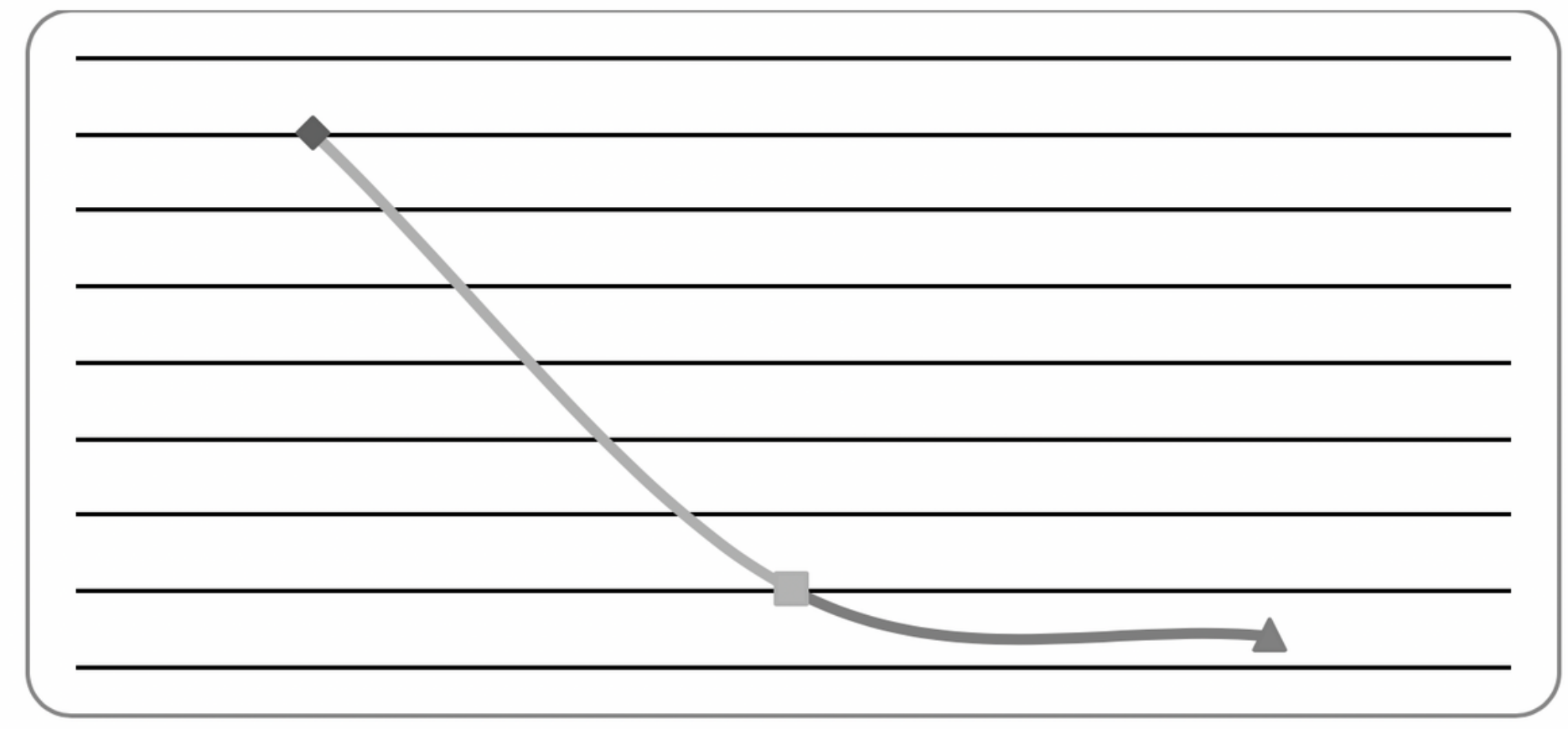

Figure 4

Table 04. Decision to be Entrepreneur 